\title{
STUDENTS' PRONOUNCIATION ERROR MADE IN SPEAKING FOR GENERAL COMMUNICATION
}

\author{
Maria Ramasari ${ }^{1}$ \\ English Department, STKIP PGRI Lubuklinggau \\ mariaramasari@gmail.com ${ }^{1}$
}

Submit, 08-11-2017 Accepted, 30-12-2017 Publish, 30-12-2017

\begin{abstract}
This qualitative research described students' pronunciation error mostly appeared in speaking for general communication class. The participants were the first semester students. This research was descriptive method. It involved describing, analyzing, and interpreting of condition that existed. In collecting the data, the researcher used documentation. Based on the result of data analysis, it could be concluded that students made of three types of pronunciation error. The pronunciation errors were pre-systematic error, systematic error, and postsystematic error. Furthermore, the students' dominant error made was presystematic error. The errors of students' made were caused by three sources of students' competence error in learning English as Foreign Language. They were interference error, intra lingual error, and developmental error.
\end{abstract}

Keywords: pronunciation, error, speaking for general communication.

\section{INTRODUCTION}

The use of English in oral communication is one of the most common, but completely complex activities to be considered when teaching English was as Foreign Language (EFL). It is because English speaking ability has became a must, especially who wanted to advance in certain fields of human endeavor (AlSibai, 2004:3). Teaching English as Foreign Language is a big challenge for teachers in Indonesia. It is also faced by lecturers in college level, whereas the lecturers should do strategies or techniques in teaching and learning process. This happens because of many reasons. In the writer point of view, based on the observation in her classroom, she found that students tended to be inactive in using English for their life activities especially in classroom. In other words, EFL students only use English for certain purpose; only in classroom when they were let to speak English. For other activities, such as asking questions or clarifying something, they were not confident to practice English.

There are four basics skill in learning English which should be improved by students. Ur (1996:120) considered speaking as the most important skill among four skills (listening, speaking, reading, and writing) because people who know a 
language, are referred to as speakers of that language. Speaking as one of skills becomes crucial for students when they learn English. It is also as hard thing to be done. Almost students in Indonesia, who learn English as Foreign Language, create their mindset for learning English as a negative stereotype especially to speak English. Most people especially English learners, speaking a foreign language has often meant a difficulty (Nunan, 2003:342). Due to the fact in teaching English for speaking skill needs extra strategies to build the students' positive mindset and environment. Teaching strategies could be as media to let students enjoyed for speaking English.

In improving students' speaking ability, of course, is to improve the oral production of students. In other words, there are some essential elements that should be paid attention. The essential elements in speaking are such as vocabulary, pronunciation, grammatical function, intonation, stress, fluency and others. The focus of this research is pronunciation. As stated by Richard and Schmidt (2002:440) pronunciation is the way a certain sound or sounds are produced. It is unlike articulation which refers to the actual production of speech sounds in the mouth, pronunciation stresses more the way sounds are perceived by the hearer, e.g.: You haven't pronounced this word correctly, and often relates the spoken word to its written form, e.g.: In the word knife, the $k$ is not pronounced. Therefore, teaching of speaking have to focus on improving the oral production of students, including pronunciation.

\section{LITERATURE REVIEW}

\section{Pronunciation in Communication}

According to Hornby (2008:352) pronunciation is way in which a language or particular word or sound is spoken. Pronunciation is very important to be learned, especially in speaking skill. Pronunciation is the way in which people make sound of words. However, many students find pronunciation as one of the most difficult aspects in learning English. Students that have good pronunciation in speaking English are more likely to be understood even if they make errors in other aspects. Whereas students with bad pronunciation must be difficult to be understand, even if the grammatical used of them are perfect.

The main speaking difficulties encountered by students are linguistic difficulties, mother tongue use, and inhibition (Al Hosni, 2014:28). Students are unable to speak in English because they lack the necessary vocabulary items and grammar structures. They also lack sentence formation skills, which result in using the mother tongue. Students also think of making mistakes in speaking in front of their classmates very embarrassing, which results in preferring not to speak to avoid such situations. It is not easy to let students in speaking English by using correct pronunciation. It needs more time and suitable strategy. English as Foreign 
Language (EFL) is one of basic reason why students had difficulties for pronouncing the words correctly.

\section{Errors or Mistakes}

The students, of course, will do errors or mistakes in speaking activities especially in pronouncing the words. The different system of language could make students to make errors and mistakes. The analysis of students' pronunciation error, in learning English as Foreign Language, needs to be done. It should be important to distinguish between errors and mistakes. According to Corder (1974:29) errors are typically produced by people who do not yet fully command some institutionalized language system; true errors are marker of the students' competence. An error is noticeable grammar from the adult grammar of native speaker, reflecting the inter language competence of the learners (Brown, 1980:165). In simple words, it could be concluded that error refers to the failure in using the system of language correctly. It is caused by the lack of the students' competence, knowledge and comprehension.

Mistake must be different to error. A mistake refers to a performance error that is either random or a slip of the tongue, in that it is failure to utilize a known system correctly. In addition, mistakes are caused by hesitation, slips of the tongue (Brown, 1980:165). Mistake refers to the failures to use the language system correctly caused by some factors such a carelessness, memory lapses, and physical condition. The students, who make mistakes, will be inconsistency. They sometime do once mistake and sometime do more than once mistakes. The examples of students' mistake done are: the students should study and the students should to study. According to Richards (1974:124) the sources of errors in studying a language might be derived from the interference of the learners' mother tongue and the general characteristics of the rule learning. The errors that are caused by the general characteristics of the rule learning are also called the intra language errors, and the errors caused by the interference of the learners' mother tongue are called the inter language errors. Richards (1974:124) distinguishes three sources of competence errors:

1. Interference errors occur as a result of the use of element from one language while speaking another. An example might be when a German learner of L2English says, "I go not" because the equivalent sentence in German is "Ichgehe nicht".

2. Intra lingual errors' reflect the general characteristics of rule learning such as faulty generalization, incomplete application of rules and failure to learn conditions under which rules apply.

3. Developmental errors occur when the learner attempts to build up hypotheses about the target language on the basis of limited experience. 
Based on the explanation above, the researcher formulated that error was part of students' process in learning English as Foreign Language. The process could allow the students' improvement to get a progress in being better if they could correct the errors. In correcting the errors, students need lecturer's evaluation to identify the errors made by students in speaking. For that reason, the researcher as lecturer was interested to analyze the students' errors speaking for general communication. The result of this analysis could give significances for herself or her students. The students' error made would be as evaluation for the researcher herself and the students. In other words, the lecturer could identify and correct the grammatical errors of students so that it was hoped that the students' errors could be minimized.

Furthermore, Ur (1996:78) argued that there are many factors that cause difficulty in speaking, and they are as follows:

1. Inhibition, students are worried about making mistakes, fearful of criticism, or simply shy.

2. Nothing to say, students have no motive to express themselves.

3. Low or uneven participation, only one participant can talk at a time because of large classes and the tendency of some learners to dominate, while others speak very little or not at all.

4. Mother tongue use, learners who share the same mother tongue tend to use it because it is easier and because learners feel less exposed if they are speaking their mother tongue.

Corder (1974:56) conveyed that there were three types of errors. They were pre-systematic, systematic, and post-systematic. Below the errors' types were explained.

1. Pre-systematic Errors

This error occurred when the learner was unaware of the existence of a particular rule in the target language. These happened in random situation. The learner could not give any account of why a particular form was chosen.

2. Systematic Errors

This error occurred when the learner had discovered a rule but it was the wrong one. The learner was unable to correct the errors but could explain the mistaken rule used and type.

3. Post-systematic Errors

This error occurred when the learner known the correct target language rule but used it inconsistently (makes a mistake) the learner could explain the targetlanguage rule that was normally used. 


\section{RESEARCH METHOD \\ Research Design}

This study analyzed the first semester students' pronunciation error in speaking for general communication at STKIP PGRI Lubuklinggau in academic year 2016/2017. This research aimed to investigate and describe pronunciation errors made by students. Qualitative study using descriptive method was applied by the researcher in conducting this research, because she wanted to describe the existing phenomenon in such a way that found out the students' error in speaking for general communication. Donald (2010:440) stated that descriptive method describes events as they naturally occur. It involved describing, analyzing, and interpreting of condition that existed. In short, the researcher did not manipulate the data, she just wanted to describe by presenting all the facts and the conclusion based on the data collecting.

\section{Technique in Collecting the Data}

The instrument used in this research was observation, interview, documentation, and transcription to collect the data.

\section{Observation}

Observation is a systematic data collection approach. Observation is as the systematic description of events, behaviors, and artifacts in the social setting chosen for study (Marshall and Rossman, 1989:79). The researcher observed by writing and identfying the activities happened in detail of the classroom and recorded the activities. Researcher used all of their senses to examine people in natural settings or naturally occurring situations.

\section{Interview}

According to Cohen, Manion, and Morrison (2007:349) interview is a flexible tool for data collection, enable multi-sensory channels to be used: verbal and non-verbal. In simple, the researcher did interview some students in getting the additional information related to the data collection. The researcher gave eight questions for each student to get clarification about their pronunciation errors made in speaking for general communication.

\section{Documentation}

There are some methods of collecting the data, namely test questioner, interview, observation and documentation (Arikunto, 2006:137). In this research, the researcher conducts a research through documentation as a research instrument to collect the data. Documentation is documents used as evidence or proof. Document itself means an official paper that gives information, evidence, etc. Hornby (2008:132) said that documentation records the details of something or proves something with documents. In addition, documentation is get the direct 
data from research place such as activity report, pictures, video, etc (Arikunto, 2010:77). Thus as documentation of this research, the researcher used many theories from sources of data and recorded students' speaking for general communication class to analyze students' pronunciation error made in speaking for general communication at the first semester of STKIP PGRI Lubuklinggau. The researcher asked to all students for recording their speaking ability by choosing one topic that has been discussed in the first semester for about 5 till 10 minutes. The recording was done in the last meeting of the first semester in academic year 2016/2017.

\section{Transcribing Data}

The researcher copied all data from a video camera to notebook Acer in Microsoft Word. Then, she marked and classified the pronunciation errors' types introduced by Corder (1974:89) on the data transcription.

\section{Technique in Analyzing the Data}

In this research, the researcher used five steps of data analysis that is taken from Cohen, Manion, and Morrison (2007:349). The steps were: recording the students spoken, transcribing the students spoken, eliminating redundancy of the students spoken, identifying the students' transcription, and compositing summary of the research. The population is entry group of individuals or items in which statistical measurement is investigated. Therefore, the total number of first semester students as the subject of the research was 37 students.

Table 1 Subject of the Research

\begin{tabular}{ccc}
\hline No & Class & Number of Students \\
\hline 1 & $1 \mathrm{~A}$ & 23 \\
\hline 2 & $1 \mathrm{~B}$ & 14 \\
\hline & Total & $\mathbf{3 7}$
\end{tabular}

Source: STKIP PGRI Lubuklinggau in the academic year 2016/2017

\section{FINDING}

The research of students' pronunciation error made in speaking for general communication, was done for the first semester students of English Education Study program at STKIP PGRI Lubuklinggau in academic year 2016/2017. The result of data analysis explained based on the formulation of problems; 1) what were the students' pronunciation error made in speaking for general 
communication? 2) What were the students' pronunciation dominant errors made in speaking for general communication? 3) What were the causes of students' pronunciation error made in speaking for general communication?.

It was found that three types of pronunciation errors made by students in speaking for general communication. The error identification was taken from Corder (1974:90). They were pre-systematic errors, systematic errors, and postsystematic errors. Moreover, the researcher just focused on students' error in pronunciations when they practiced their speaking ability for general communication class in the first semester. The use of data comparative was Dictionary of Language Teaching and Applied Linguistics Third Addition (Richard and Schmidt, 2002:56). It was used by the researcher to analyze the students' pronunciation errors in speaking for general communication. In Dictionary of Language Teaching and Applied Linguistics Third Addition, there were phonological symbols based on International Phonological Alphabet (IPA). Therefore, the researcher could evaluate the pronunciation errors made by students in speaking for general communication.

\section{DISCUSSION}

\section{Pre-systematic Errors Made by Students in Speaking for General Communication}

These errors' type occurred when the students were unaware and out of control while speaking. They tended to ignore the way how speak by using correct pronunciations so that when they speak English, they were not feeling for incorrect pronunciations made by themselves. The other students as the listeners of student who spoke only could listen without any correction. Imitation was a problem that was not broken. In this error type, the researcher found sixty nine words that were pronounced incorrectly by students. There were thirty six words with repetition, they were: student, giving, students, video, excuse, floor, waiting, general, lecturer, know, visitor, left, direction, because, pardon, walking, beautiful, near, answer, afternoon, material, confused, about, caused, apologize, response, study, what, expression, language, written, morning, that's all, choose, assignment, response.

From those data, the researcher stated that there were many words that were errors pronounced by students. When the researcher clarified the students' error by interviewing them one by one, the fact was they did not realize at all the errors. In addition, they were not fully aware to evaluate and correct the pronunciations by themselves. The pronunciation errors of students were made by students as repetitions in their speaking activities.

\section{Systematic Errors Made by Students in Speaking for General Communication}

The errors occurred for the students who had got the comprehension about the rule of language function; they had errors for the practice. The students fully 
aware the rule of phonological symbols in pronunciations, but they could be errors in pronouncing the words. They also could unable to evaluate and correct the errors. The example words that were systematic errors made by students; the word was data. The proper phonological word should be /'dertə/. The fact was students did the errors continuously, although the lecturer had corrected the error by asking the students to repeat the correct pronunciation of the word data. The students did the error for many their speaking practice. Some students pronounced the word data as /'data/, others pronounced /'dətə/.

The other word was beautiful and places. The word beautiful was pronounced by students as /'bjutiful/ or /'biutipul/. Even though, the correct pronunciation and proper phonological word should be /'bju:trfl/. Hereafter, the word places was also error pronounced by most of students. They often pronounced the word places as /ples/. The others tended to ignore the $-\mathrm{s}$ as plural form of the word places. When the lecturer asked them to correct the pronunciation, they had difficulties to pronounce the word well. It took a few rehearsals to produce the correct pronunciation. Students needed to open their dictionary to be easier in pronouncing the word correctly. The proper phonological word must be /plessis/.

The data above described that students faced difficult to pronounce the certain words with the correct pronunciations and proper phonological words. Actually, they had known to pronounce the words well. However, because of the familiarity they pronounce the words incorrectly. Some efforts had done by lecturer, the practice to pronounce the words repeatedly and let the students to correct the error directly. The result showed that students got the comprehension for the rule of language function in pronunciation/ proper phonological but they were still errors in pronouncing the words. Finally, the students who were categorized into systematic errors had a self reminder when they did the errors. They tried to correct the errors. This became the third errors' type; it was called post- systematic error.

\section{Post-Systematic Errors Made by Students in Speaking for General Communication}

These errors occurred when the students comprehended the correct pronunciation/ proper phonological of target language English, but they used the rules inconsistently for speaking practice. It means that they spoke English by using correct pronunciation for some chances, and the other chance they could speak English by using in correct pronunciation. The data showed that students who were corrected by lecturer for more than three times, they were aware automatically by themselves to correct the errors' pronunciation made by them.

Further, the types of post-systematic errors were done by some students. The word as an error was the article the. Firstly, students did not get the rule of proper 
phonology for distinguishing pronunciation between /ði/ and /ðe/. They pronounced the all article the by a pronunciation as /ðe/. Then, the lecturer corrected by explaining the rules that the article the must be pronounced/ðe/ if the article the meets the words with consonants in the first places. Article the is placed before a word which has the vowel. It must be pronounced as /ði/.

In this case, the students who did the errors, corrected by themselves automatically without any correction from lecturer. However, some situation the lecturer should give signals to students in correcting the errors. The students responded quickly to read the signals given by lecturer. The post-systematic errors could occur when the students got the explanation of language rule in pronunciation with the proper phonological. Yet, they needed a process by stopping for a while to correct the errors. From the data above, it could be described that students did three types of errors to pronounce words in speaking for general communication. In addition, it could be said that the dominant error's type made by students was pre-systematic errors. There were sixty nine words that were categorized into pre-systematic errors. Moreover, there were thirty six errors made by students repeatedly. The students' percentage did the errors were 67.56 $\%$.

\section{The Causes of Students' Pronunciation Error Made in Speaking for General Communication}

The researcher continued in analyzing the causes of students' pronunciation error made in speaking for general communication. The researcher used the theory of Richards (1974:124) that there were three causes of errors. First is an interference error that occurs as a result of the use of element from one language while speaking another. Second is intra lingual errors' reflecting the general characteristics of rule learning such as faulty generalization, incomplete application of rules and failure to learn the conditions of the rules' applied. Third is developmental errors that occur when the learner attempts to build up hypotheses about the target language on the basis of limited experience.

It was found out that students did three causes of errors. The first, students' causes of pronunciation errors made was interference error. This cause was done by students because the influence of other languages, first language acquisition or students' mother tongues. Students' first language acquisition with dialect, accent, and culture influenced students' pronunciation in speaking English. Students who shared the same mother tongue, tended to use the pronunciation because it is easier and students felt less exposed if they were speaking by copying dialect or accent of their mother tongue to pronounce the utterances in English.

During the researcher's class observation, she noticed that almost students spoke in Bahasa Indonesia when they discussed the material in classroom discussion, and when I asked them to clarify the reasons in interview; they 
explained that by saying, they want to convey ideas in English, but they do not know how to say it. It was very difficult to state our opinion by using correct pronunciation in English. It meant that when they could speak English. However they were not confident to try in conveying the ideas by using English because of their lack pronunciation. Further, students explained that their fear of making mistakes in front of their classmates was the reason for not speaking in the class. They expressed that 'my classmates will laugh at me if I make mistakes or errors'. The data collected showed that some words that were pronounced incorrectly, students did errors. The interview with students also pointed out that they had difficult to pronounce some words when they try to state an opinion in speaking. One of them said, I do not know how to say it, and I am not sure for my pronunciation although my lecturers spend a long time teaching about phonology and pronunciation. Students still confuse and free to pronounce words in utterances when they try to speak in English. The researcher identified that some students made the pronunciation/ phonological errors for $/ \mathrm{b} /$. The phoneme $/ \mathrm{b} /$ is called bilabial stops. It is pronounced by closing the lips tightly, and then the air is let out suddenly. It includes a voiced consonant-vibrating the vocal cords and it is not aspirated. However, some students had difficulties in pronouncing words that use phoneme /b/. They tended to pronounce the phoneme /b/ became heavy and reflected the tongue severe. In many cases, but not all, it was done by students who had Javanese language as their first language. The words were such as back, by, symbol, behind, behave, sibling, both, and others.

The second caused of students' pronunciation errors was intra-lingual error. It was reflected by students' general characteristics of rule learning. It included to inhibition, students are worried about making mistakes, fearful of criticism, or simply shy. Based on the data analyzed, students were likely errors for generalization. Students also faced difficult to distinguish between the phoneme /ð/and /d/. They decreased their mother tongue dialect and accent in pronouncing English words, for example define, tall, riding, writing, wanted, ordered and soon. Both /d/ and /ð/ are called alveolar stops. They are pronounced by putting the tip of the tongue against the alveolar ridge, while the sides of the tongue are held against the upper teeth. The English phoneme /ð/ is a voiceless consonant, when it is not preceded by /s/, it must be aspirated. However, the phoneme /d/ is a voiced consonant, and it must be aspirated. Both /ð/ and /d/ can occur in all position.

In addition, the researcher also found out that students had difficulties in pronouncing among /s/ and /z/, /f/ and /v/, or /e/ and /æ/. Because of their interference errors, students of EFL did not realize that their mother tongue has affected their pronunciation of English, either accent or dialect when they spoke in speaking for general communication. Actually, the phoneme /s/ and /z/ are called 
sibilants, for example the words racing and raising. They are formed by producing a rather deep groove in the center of the apex of the tongue. The groove forms a narrow passage through which a jet of air is directed at the lower edge of the upper front teeth. Then, the phoneme /f/ and /v/ are called labio-dental fricatives; /f/ is voiceless, examples define, fast and safe; /v/ is voiced, examples reviews, save, and leave. They are formed by raising the lower lip toward the upper teeth so that air passing through the opening can be heard. The phoneme /e/ is a lower mid front lax vowel. It is formed by raising the front of the tongue to the lower mid part, and the tongue is held loosely. On the other hand, the phoneme /æ/ is a higher low front tense vowel. It is made by raising the front of the tongue to a rather higher position, and the tongue is held by some muscular tension. Both /e/ and /æ/ can occur in initial and medial positions, but not in final position. The examples are end, and, pen, guess, pan and gas.

The third caused was developmental error. It occurred because students' lack of inter language knowledge. Students could be nothing to say. They had no motive to express themselves. They also had low or uneven participation; only one participant could talk at a time because of large classes and the tendency of some students to dominate, while others spoke very little or not at all. They made evaluation for correcting the errors by themselves, but they still had incorrect pronunciation. For example they pronounced the word correspondence. Its word should be pronounced /, kprI'sppndəns/. In fact, some students pronounced it by the first syllable only for /kores/. Automatically, they stopped for a while and evaluated by correcting the pronunciation. But, they are not sure to improve their pronunciation into correct way. They tried to look for the best correction of the word correspondence to be /kprespondens/. It was corrected by the lecturer; however students did the errors consistently for other chance.

\section{CONCLUSION}

Based on the explanation of finding and evaluation above, the researcher concluded that: First, there were three types of students' pronunciation errors. They were pre-systematic errors, systematic errors and post-systematic errors. Second, the dominant type of students' pronunciation error was pre-systematic errors. Third, there were three causes of students' pronunciation errors. They were interference errors, intra lingual errors, and developmental errors. In speaking for general communication classroom interaction, lecturer and students had influenced each others. The lecturer had responsibilities to evaluate and correct the students' error by identifying the errors made by students consistently, especially when they practiced the correct pronunciation in speaking skill. Furthermore, students also should be active learners in evaluating and correcting the pronunciation themselves. They have to develop their pronunciation improvement by comprehending the theoretical about proper phonological 
utterance in speaking English for communication. They also should avoid to copy-paste the way of their first language used into speaking English practiced.

\section{REFERENCES}

Al Hosni, Samirah. (2014). Speaking Difficulties Encountered by Young EFL Learners. International Journal on Studies in English Language and Literature (IJSELL) Volume 2, Issue 6, June 2014, PP 22-30.

Al-Sibai,D. (2004). Promoting oral fluency of second language learners: Educational linguistics. Department of English: King Saud University.

Arikunto, Suharsimi. (2006). Prosedur Penelitian: Suatu Pendekatan Praktik. Jakarta: Asdi Mahasatya.

Arikunto, Suharsimi. (2010). Pendidikan Dasar-Dasar Evaluasi. Jakarta: Bumi Aksara.

Brown, H. Douglas. (1980). Principles of Language Learning and Teaching. Englewood Cliffs: Prentice-Hall, Inc.

Cohen, L., Manion, L., \& Morrison K. (2007). Research Methods in Education (5th Edition). London: Routledge Falmer.

Corder, S.P. (1974). Error Analysis. London: Longman.

Donald, Ary. (2010). Introduction to Research in Education. New York: Nelson Education, Ltd.

Hornby, A. S. (2008). Oxford Advanced learner's Dictionary of Current English. New York: Oxford University Press.

Marshall, Catherine, Rossman, Gretchen B. (1989). Designing Qualitative Research. Newbury Park, CA: Sage Publications.

Nunan, David. (2003). Practical English Language Teaching. New York: McGraw Hill.

Richard, Jack. C., Schmidt, Richard. (2002). Longman Dictionary of Language teaching and Applied Linguistics (3rd edition). London: Longman.

Richards, J.C. (1974). Error analysis Perspectives on Second Language Acquisition. London: Longman.

Ur, Penny. (1996). A Course in English Language Teaching (1st Edition). Cambridge: Cambridge University Press. 